\title{
Review on Effects of Various Inorganic Fertilizers and Cattle Manure on the Tuber Yield and Quality of Potato (Solanum tuberosum L) in Ethiopia
}

\author{
Biratu Abeshu \\ Wollega University Shambu Campus. P.O.BOX 395, Shambu, Ethiopia
}

\begin{abstract}
Potato (Solanum tuberosum L.) is one of the most important and widely cultivated vegetable crops in Ethiopia. The application of organic and inorganic fertilizers highly influence yield and quality attributes of potato. In this article, the effects of different inorganic and organic fertilizers on potato yield and quality were reviewed. Potato yields explained in different terms like total tuber yield, marketable tuber yield, storage tuber weight, and unmarketable tuber yield. And qualities were dry matter, specific gravity, and starch. Fertilizers like nitrogen, phosphorous potassium, and blended fertilizers; like NPSB, NPS, NPSZB, NBS, KCL, and organic fertilizer cattle manure is major fertilizer used in potato production in Ethiopia. These fertilizers are influence yield and quality of potato in both combined and alone application forms. The application of inorganic and organic fertilizer was positively affected yield and quality attributes of potato. However, the combined application form enabled to obtain higher yields and quality than sole application. However, it enhances productivity; the sole application of inorganic fertilizer has a negative impact on soil characteristics. Cattle manure improves soil structure and increases the yield. During the combined application of inorganic and organic fertilizer, the yield and quality obtain were high and soil structure might not be affected that's why a low amount of inorganic fertilizer is utilized. Therefore, the integrated use of inorganic and organic fertilizers was suggested as the better option in obtaining higher yields, improvement in the quality of potato, and soil structure.
\end{abstract}

Keywords: Cattle manure, Dry matter, Inorganic fertilizer, Starch, Total tuber yield.

DOI: $10.7176 / \mathrm{JBAH} / 10-22-01$

Publication date: November $30^{\text {th }} 2020$

\section{INTRODUCTION}

Potato (Solanum tuberosum L.) is one of the most popular and widely cultivated vegetable crops in Ethiopia (Bekele, 2018). It is important food security and cash crop for smallholder farmers (Ababulgu, 2018) and one of the major food crops in the mid and high altitude areas of Ethiopia. The crop recognized as a famine relief crop at the end of the rainy season when cereal crops are not ready for harvest, especially in the highland areas, where cereals mature after an extended period (Balemi, 2012). Potato is grown commonly and is adaptable in wide ranges of climatic conditions; it has strict requirements for a balanced fertilization $t$ which yield and quality of tubers are directly affected. Potato is heavily fertilized since they have high nutritional requirements (Ahmed et al., 2015). The potato was introduced to Ethiopia in 1858 and $70 \%$ of Ethiopian land, mainly in the highland is suitable for potato growing (Zewudie et al., 2016). Since then, the potato has become an important garden crop in many parts of Ethiopia and it ranks first among root and tuber crops in volume produced and consumed followed by Cassava, Sweet potato, and Yam (CSA, 2017). It is a high potential food security crop in Ethiopia due to its high yield potential, nutritional quality, short growing period, and wider adaptability (Tewodros et al., 2014). About $1,571,806$ farmers are engaged in potato growing with an area of 74, 935 ha per season with an annual production of 8.6 M. quintal (CSA, 2013). Total production of 921,403.2ton cultivated by over 1.2million households (CSA, 2017 ) with the productivity of (13.8 $\left.\mathrm{t} \mathrm{ha}^{-1}\right)$ (CSA, 2017).Both yield and tuber qualities are affected by variety, environmental conditions, and cultural practices. Fertilizer application has important effects on the yield and quality of potatoes (Westermann, 2005). Nitrogen is a vital nutrient for the activity of plant organs. It is important for many components such as amino acids, nucleic acids, and leaf chlorophyll content (Najm et al., 2012a).

The conventional use of chemical fertilizer can increase the tuber yield but inordinate use of nitrogen has a negative effect on tuber quality, environment pollution, public health, and economical losses and reduces starch, dry matter, and sugar contents in tubers. Ultimately huge loss during the storage (Balemi, 2012).

Besides the application of mineral fertilizers to potatoes, the importance of cattle manure is being recognized because of the increased cost of mineral fertilizers from time to time and their long term effects on soil chemical properties (Negassa et al., 2001). It is also useful in improving the efficiency of fertilizer recovery thereby resulting in higher crop yield and quality (Gedam et al., 2008). Organic manures and their extracts have been reported to improve soil fertility, soil structure, and furthermore help plants in combating pests and diseases (Khadem et al., 2010). Cattle manure is a potential source of organic fertilizer in Ethiopia, as the country has the highest livestock number in Africa (Zinash, 2001). Cattle manure seems to act directly in increasing crop growth and yields either by accelerating the respiratory process with increasing cell permeability and hormonal growth action or by the 
combination of all of these processes which supply $\mathrm{N}, \mathrm{P}$ and $\mathrm{S}$ in the available form to the plants via biological decomposition and improves physical properties of soil such as aggregation, permeability, and water holding capacity. Cattle manure contains a large number of nutrients and influences plant growth and production via improving chemical, physical, and biological fertility. The application of organic manure and inorganic fertilizers could substantially influence the yield of potato (Biruk et al., 2015). Thus, the objective of this paper is to review the effect of integrated use of cattle manure with various Inorganic fertilizer applications on yield and tuber quality of potato.

\section{Potato Production in Ethiopia}

Potato (Solanum tubrosum L.) is one of the most important food crops and leading vegetables in mid and high altitude areas of the country. It is a crop with high potential to contribute to poverty reduction and becoming an important food crop in Ethiopia. The potato crop can contribute to improving food and nutritional security. It is regarded as a high potential food security crop for densely populated highland regions because of its ability to provide a high yield per unit input with a short crop cycle than major cereal crops (Hirpa et al., 2010), hence the Ethiopian government has identified it as one of the priority crops for agricultural growth program (Tesfaye et al., 2012). The potato grows in a short period, staple food, and income source for smallholder farmers (Bekele, 2018). Especially in rainfed systems, this is of the essence, as it makes potato one of the first crops that can be harvested after the onset of the rainy season. In conditions of food shortage, this makes potato an essential hunger breaking crop to assure staple food before grains can be harvested.

Recently, the government of Ethiopia declared that Irish potato to be a national strategic food security crop (Abebe, 2013). This main policy pronouncement, qualified Irish potato for government-initiated farmer support initiatives supervised by Agricultural Research Centers through one farmer's plot seed multiplication and small scale semi-modern irrigation building. The growing importance of potato as a food crop is prefaced on rising food insecurity in the country. Increasing potato production on a sustainable basis will enable the crop to assert as a national strategic food security crop and help ease the food security challenges of the country. Potato production is enhanced by the combined application of different organic and inorganic fertilizers. Bekele (2018), has reported that the application of blended NPSZnB fertilizer in combination with cattle manure was found to be important for the yield and quality of potato. The application of blended NPSZnB fertilizer and cattle manure resulted in better performances for some yield and quality variables.

\subsection{The Response of Potato Yield to Combined Application of Cattle Manure and Inorganic Fertilizer.}

An integrated nutrient management system is to supply crops with balanced nutrition to maintain and improve soil fertility as well as soil health for sustained high productivity on a long- term basis and also to reduce fertilizer input costs (Wondimu, 2011). The use of inorganic fertilizer and cattle manure highly influence Growth parameters of potato. According to Bekele (2018), the combined application of blended NPSZnB fertilizer and cattle manure showed a significant increase in marketable tuber yield, total tuber yield, total dry biomass of potato and maximum marketable tuber yield $\left(31.7 \mathrm{t} \mathrm{ha}^{-1}\right)$, maximum total tuber yield $\left(34.1 \mathrm{t} \mathrm{ha}^{-1}\right)$ and maximum total dry biomass yield $(185.35 \mathrm{~g} / \mathrm{hill})$ was obtained due to combined application of both fertilizers. Combined application of NPS blended fertilizer and CM improved yield of potato. Accordingly, optimum tuber yield was obtained from the combined application of $150 \mathrm{~kg} \mathrm{ha}^{-1}$ NPS blended fertilizer and 20- $30 \mathrm{t} \mathrm{ha}^{-1}$ (Ababulgu, 2108).

Koroto (2019) also reported the main effects of FYM and mineral NP fertilizers highly significantly affected marketable and total tuber yields. However, their interaction did not significantly influence these parameters, and the main effects as well as their interaction did not significantly influence the unmarketable tuber yields. The interaction effects of $\mathrm{N} \times \mathrm{P}, \mathrm{N} \times \mathrm{CM}$, and $\mathrm{N} \times \mathrm{P} \times \mathrm{CM}$ were also significant on total and marketable tuber number and the highest total and marketable tuber numbers were obtained at the combined application rates of $120 \mathrm{~kg} \mathrm{~N}$ $\mathrm{ha}^{-1}+92 \mathrm{~kg} \mathrm{P}^{2} \mathrm{O} 5 \mathrm{ha}^{-1}+10 \mathrm{t} \mathrm{CM} \mathrm{ha}^{-1}$ followed by the application of $120 \mathrm{~kg} \mathrm{~N} \mathrm{ha}^{-1}+92 \mathrm{~kg} \mathrm{P} 2 \mathrm{O} 5 \mathrm{ha}^{-1}+5 \mathrm{t} \mathrm{CM}$ ha $^{-1}$ (Merga et al., 2018).

The interaction of nitrogen and phosphorus was highly significantly influenced the marketable tuber yield. Table 2 shows the yield attributes of Gudane variety obtained as the result of application of blended NPS fertilizer. Combined application of nitrogen at the rate of $165 \mathrm{~kg}$ and $135 \mathrm{~kg} \mathrm{P}^{-1}$ gave the highest marketable tuber yield $\left(36.13 \mathrm{t} \mathrm{ha}^{-1}\right)$ while the lowest marketable tuber yield $\left(19.18 \mathrm{t} \mathrm{ha}^{-1}\right)$ was recorded for the control plot (Belachew, 2016). The interaction effect of $P$ and FYM resulted in significant increases in average tuber weight in response to the increased application of higher rates of the two fertilizers (Wondimu and Dechassa, 2011).

The application of different rates of inorganic fertilizers such as ( $\mathrm{N}$ and $\mathrm{P}$ ) along with different levels of organic manures FYM significantly increased the marketable tuber and total tuber yield compared with plants that received no treatments (Table1). Total tuber yield also followed in the same trend and it was also highest for those treatments which had shown the highest marketable yield. This indicates that the application of higher rates of farmyard manure and inorganic fertilizer is required to get the highest tuber yield provided that the availability of organic and inorganic fertilizers (Mohamed et al., 2018). 
Table1. Interaction effect of P and FYM on marketable tuber yield, unmarketable tuber number and total tuber yield (wondimu and Dechasa, 2011)

\begin{tabular}{|c|c|c|c|c|}
\hline \multicolumn{3}{|l|}{ Treatment } & \multicolumn{2}{|c|}{ parameter } \\
\hline $\begin{array}{c}\mathbf{P} \\
\left(\mathrm{kg} \mathrm{P}_{2} \mathrm{O}_{5} \mathrm{ha}^{-1}\right)\end{array}$ & $\begin{array}{l}\text { FYM } \\
\left(\mathrm{t} \mathrm{ha}^{-1}\right)\end{array}$ & $\begin{array}{l}\text { MTY } \\
\left(\mathrm{t} \mathrm{ha}^{-1}\right)\end{array}$ & $\begin{array}{l}\text { UMTN } \\
\text { (No/plot) }\end{array}$ & $\begin{array}{l}\text { TTY } \\
\left.(\mathrm{t} \mathrm{ha})^{-1}\right)\end{array}$ \\
\hline $\mathbf{0}$ & 10 & $10.81^{\mathrm{cd}}$ & $99.0^{\mathrm{a}}$ & $11.95^{\mathrm{cd}}$ \\
\hline $\mathbf{0}$ & 20 & $11.63^{\mathrm{abc}}$ & $68.11^{b}$ & $12.68^{b c}$ \\
\hline 46 & 10 & $14.92^{\mathrm{ab}}$ & $78.22^{\mathrm{ab}}$ & $16.05^{\mathrm{a}}$ \\
\hline 46 & 20 & $11.98^{\mathrm{abc}}$ & $77.89^{\mathrm{ab}}$ & $13.08^{\mathrm{bc}}$ \\
\hline 92 & 0 & $12.75^{a b c}$ & $81.56^{\mathrm{ab}}$ & $13.94^{\mathrm{bc}}$ \\
\hline 92 & 10 & $13.02^{a b c}$ & $70.33^{b}$ & $14.06^{\mathrm{bc}}$ \\
\hline
\end{tabular}

\subsubsection{The yield of potato.}

Potato yield is one the main factor makes intensively cultivate potato worldwide. It functions as a source of nutrients like carbohydrate, protein, vitamins, and minerals. According to (MoARD, 2011), potato is known to supply carbohydrates; high-quality protein, and a substantial amount of essential vitamins, minerals, and trace elements. The yield of potato tubers is considered to be a function of four processes: radiation interception, conversion of intercepted radiation to dry matter, partitioning of the dry matter between the tuber and the rest of the plant, and regulation of tuber dry matter (Millard and Marshall, 1986). Potato yield is highly influenced by the application of both organic and inorganic fertilizer. The size and number of potato tubers are varied due to soil amendments. Bekalo (2017) reported that yield and yield components of potato were significantly affected by soil amendments. Potato plants are grown in soils amended with sole blended fertilizer, half FYM combined with RNP and half FYM and blended fertilizers resulted in improved fresh yield

\subsubsection{Total tuber yield.}

Total tuber yield is the summation of different underground potato tubers which categorized depending on different factors. Total tuber yield increased almost linearly with increased rates of the combination of P and FYM as well as the combination of $\mathrm{N}$ and $\mathrm{P}$. Thus, the maximum total tuber yield was attained at the combination of $92 \mathrm{~kg} \mathrm{P}_{2} \mathrm{O}_{5}$ $\mathrm{ha}^{-1}$ and $20 \mathrm{t} \mathrm{FYM} \mathrm{ha}^{-1}$ (Wondimu and Dechassa, 2010). Zewide al. (2018) pointed out that the total tuber numbers/hill was obtained by adding up the number of marketable and unmarketable tubers. This parameter constituted all tubers: small, medium, large, diseased, deformed, etc that were produced by the plants.

Total tuber yield is one of the major yields and yield components of potato that mostly influenced by the application of fertilizers. According to Balemi (2012), total tuber yield was significantly influenced by the FYM + NP fertilizers treatments unlike on vertisol. The application of 20 to $30 \mathrm{t} \mathrm{ha}^{-1} \mathrm{FYM}+66.6 \%$ of the recommended inorganic NP fertilizers (110 kg N ha $\mathrm{kn}^{-1}$ and $\left.\left.90 \mathrm{~kg} \mathrm{P}^{2} \mathrm{O} 5 \mathrm{ha}^{-1}\right)\right)$ gave significantly higher total tuber yield than a full dose of inorganic NP fertilizers without FYM. On the other hand, $30 \mathrm{t} \mathrm{ha}^{-1} \mathrm{FYM}+66.6 \%$ of the recommended inorganic NP fertilizers gave significantly higher total tuber yield than a full dose of inorganic NP fertilizers without FYM. The application of $10 \mathrm{t} \mathrm{ha}^{-1} \mathrm{FYM}+66.6 \%$ of the recommended inorganic NP fertilizers and 20 to $30 \mathrm{t} \mathrm{ha}^{-1} \mathrm{FYM}+33.3 \%$ of the recommended inorganic NP fertilizers gave a total tuber yield which was on par with the tuber yield obtained due to applying a full dose of inorganic NP fertilizers alone.

Balemi (2012) demonstrated that the application of $10 \mathrm{tha}^{-1}$ and 20 or $30 \mathrm{tha}^{-1} \mathrm{FYM}$ resulted in a saving of $33.3 \%$ and $66.6 \%$ commercial NP fertilizers respectively, without significantly reducing the total tuber yield. Figure1 indicates the effect of FYM and NP fertilizer rate on the total tuber yield of potato. Increasing the application of dosage of cattle manure and mineral NP increased total tuber number per hill from 10.4880 -13.2975 count hill ${ }^{-1}$ and 9.504- 11.076 count hill $^{-1}$ in Belg and Meher season respectively (Zewide et al., 2018). Increasing the rates of nitrogen increased total tuber yield across the increased rates of both phosphorus and cattle manure. Thus, the highest total tuber yield $\left(43.44 \mathrm{tha}^{-1}\right)$, was obtained as a result of the application of the three fertilizer at the highest rates $\left(120 \mathrm{~kg} \mathrm{~N} \mathrm{ha}^{-1}+92 \mathrm{~kg} \mathrm{P}^{2} \mathrm{O} 5 \mathrm{ha}^{-1}+10 \mathrm{t} \mathrm{CM} \mathrm{ha}{ }^{-1}\right)($ Merga et al.,2018) and according to Bekele (2018) the highest total tuber yield $\left(34.1 \mathrm{t} \mathrm{ha}^{-1}\right)$ was obtained from the combined application of $199 \mathrm{~kg} \mathrm{ha}^{-1} \mathrm{blended}$ NPSZnB fertilizer and $30 \mathrm{t} \mathrm{ha}^{-1}$ cattle manure 
Figure1. Effect of FYM and NP fertilizer rate on total tuber yield of potato (Balemi, 2012)
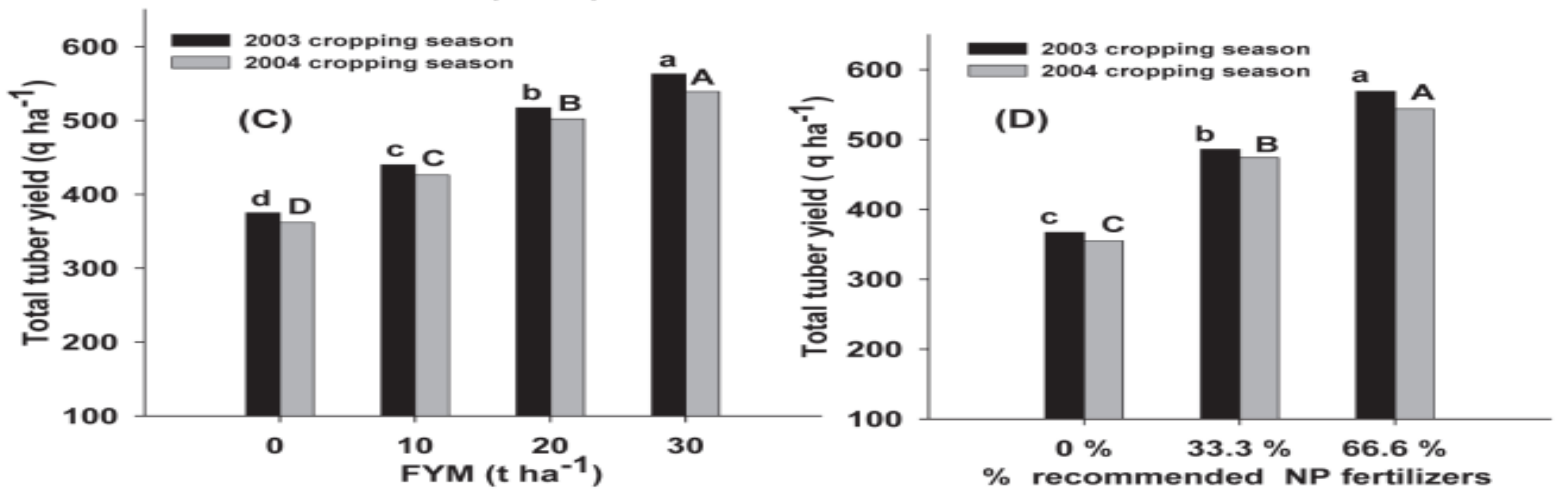

\subsubsection{Marketable tuber yield}

Marketable tuber yield: the number of tubers was counted as marketable which is greater or equal to $25 \mathrm{~g}$, free from disease, and insect attack in each plot and divided by the respective number of plants harvested (Zewide et al .2018). Marketable tuber number increased with the increased rate of cattle manure and mineral NP. The increasing rate of Cattle manure and mineral NP application from 0-7.5 t CM+75\% RDF ha ${ }^{-1}$ increased marketable tuber number from 6.2046-9.72 and 9.50-1 1.08/hill (Zewide et al., 2018). According to Mohammed et al. (2018), the highest marketable tuber yields of $38.65 \mathrm{t}$ ha-1 of potato was obtained in response to a combined application of farmyard manure, $\mathrm{N}$ and $\mathrm{P}$ at the rates of $10 \mathrm{t} \mathrm{FYM} \mathrm{ha}{ }^{-1}+111 \mathrm{~kg} \mathrm{~N} \mathrm{ha}^{-1}+92 \mathrm{~kg} \mathrm{P}_{2} \mathrm{O}_{5} \mathrm{ha}^{-1}$

Marketable tuber number was highly significantly affected by the main effects of FYM and mineral NP fertilization rates; the marketable tuber number increased linearly for both FYM and mineral NP fertilizer application. The application of inorganic fertilizer in combination with organic manure highly improves yield obtained from potato tuber. Figure 2 below showed that potato tuber cultivated by FYM and NPS fertilizer. The highest marketable tuber number per plant was recorded in the treatment that received the highest FYM tha ${ }^{-1}$ and also for the highest mineral NP fertilizers respectively. While the lowest marketable tuber number was recorded in treatment that received no fertilizers for FYM and mineral NP (Koroto, 2019)

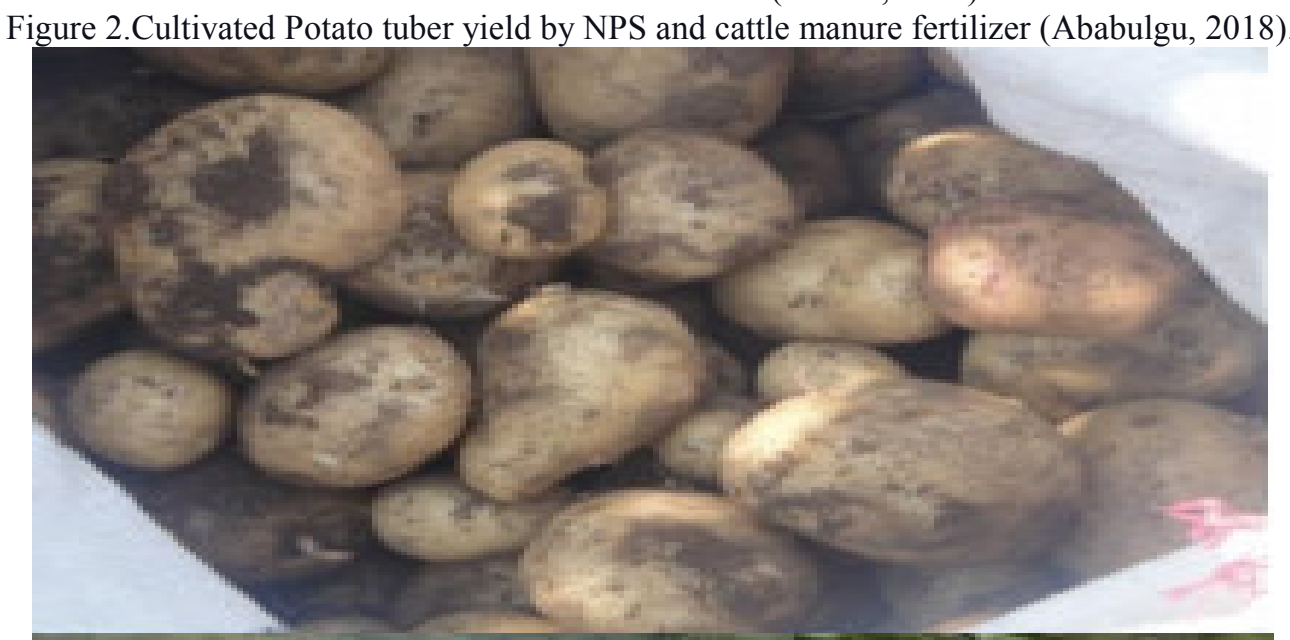

\subsubsection{Storage tuber weight.}

The size distribution of tuber was highly significantly affected by FYM and mineral NP fertilizer for mediumsized and small-sized tubers in the main effect and significantly affected for large-sized tubers. The highest proportion of large and medium-sized tubers were recorded in response to the application of the highest amount of FYM (7.5 tha $\left.\mathrm{th}^{-1}\right)$ and mineral NP fertilizers which might be due to the nutrient utilization efficiency of the crop, and the applied fertilizer pronounced better nutrient availability to increase the tuber size (Koroto, 2019). The increase in tuber size was also correlated to FYM at an increased rate which might have enhanced the available nitrogen and phosphorus to the soil which was immediately usable to the crop (Koroto, 2019). Tuber size distribution varies with many factors among which soil fertility and population density are the major ones (Haverkort et al., 2012).

According to Mohammed et al. (2018), the highest average tuber mass (134.03 g/tuber) was obtained in the plot that received $10 \mathrm{t}$ FYM ha-1 $+111 \mathrm{~kg} \mathrm{~N}$ ha-1 $+92 \mathrm{~kg}$ P2O5 ha-1 followed by application of $(111 \mathrm{~kg} \mathrm{~N} \mathrm{ha}-1$ + $92 \mathrm{~kg}$ P2O5 ha-1) inorganic fertilizers (105.5 g tuber-1) which was significantly higher than that control (83.15 g tuber-1). According to Zelalem et al. (2009), the average tuber weight progressively increased with increasing 
$\mathrm{N}$ rate up to $138 \mathrm{~kg} / \mathrm{ha}$ and tended to decrease at the highest rate of $207 \mathrm{~kg} / \mathrm{ha}$. According to Ababulgu (2018), increasing the rate of the blended NPS application from nil to $200 \mathrm{~kg} \mathrm{ha}^{-1}$ significantly increased the average tuber number per hill by about $28.57 \%$. The highest average tuber weight $(77.71 \mathrm{~g})$ was observed at blended NPS 200 $\mathrm{kg} \mathrm{ha}^{-1}$ while the lowest (60.44 g) was at the unfertilized plots. However, average tuber weight was unaffected by the application of potassium fertilizer rate.

\subsubsection{Unmarketable tuber yield.}

UN marketable tuber yield is the yield of potato which is not suitable for utilization which formed due to different factors. Among that fertilizer application is a major factor. Therefore, the application of different inorganic and organic fertilizers suggested that highly determine the unmarketable yield of potato. According to Siraj et al. (2018), the effect of blended NPSB fertilizer effect on unmarketable tuber number, while the interaction of both factors is non-significant on the unmarketable tuber number. Increasing the application of blended NPSB fertilizer from 0 to $300 \mathrm{~kg} \mathrm{ha}^{-1}$ significantly increased the unmarketable tuber number per hill.

The highest unmarketable tuber number $\left(2.92\right.$ hill $\left.^{-1}\right)$ was recorded from the application of $300 \mathrm{~kg} \mathrm{NPSB}^{-}$ ${ }^{1}$ fertilizer, while the lowest unmarketable tuber number $\left(1.8\right.$ hill $\left.^{-1}\right)$ was recorded from unfertilized treatments. Increasing the rate of blended NPS fertilizer from nil to $100 \mathrm{~kg} \mathrm{ha}^{-1}$ significantly increased the unmarketable tuber yield by about 51\% (Amdie et al, 2018). Belachew (2016) also reported that unmarketable tuber yield was significantly affected by the main and interaction effects of nitrogen and phosphorus. According to Wondimu and Dechassa, (2011), the main effects of none of the fertilizers had a significant effect on the number of unmarketable tubers. Besides, it was only farmyard manure and phosphorus that interacted to significantly influenced the unmarketable tuber number.

Table 2.Effect of blended NPS fertilizer rates on tuber yields of Gudanie potato variety (Amdie, 2018).

\begin{tabular}{llll}
\hline Blended NPS kg ha & $\begin{array}{l}\text { Marketable tuber yield }(\mathrm{t} \\
\left.\mathrm{ha}^{-1}\right)\end{array}$ & $\begin{array}{l}\text { Un marketable } \\
\text { yield }\left(\mathrm{t} \mathrm{ha}^{-1}\right)\end{array}$ & tuber \\
\hline 0 & $24.96^{\mathrm{d}}$ & $2.01^{\mathrm{b}}$ & $26.97^{\mathrm{d}}$ \\
100 & $31.31^{\mathrm{c}}$ & $3.043^{\mathrm{ab}}$ & $34.35^{\mathrm{c}}$ \\
150 & $31.71^{\mathrm{c}}$ & $2.71^{\mathrm{ab}}$ & $34.42^{\mathrm{c}}$ \\
200 & $36.41^{\mathrm{a}}$ & $3.50^{\mathrm{a}}$ & $39.91^{\mathrm{a}}$ \\
250 & $34.26^{\mathrm{bc}}$ & $3.19^{\mathrm{a}}$ & $37.45^{\mathrm{bc}}$ \\
300 & $36.06^{\mathrm{ab}}$ & $3.24^{\mathrm{a}}$ & $39.30^{\mathrm{b}}$ \\
\hline LSD $(5 \%)$ & 3.44 & 0.93 & 3.54 \\
\hline
\end{tabular}

2.3. The response of Potato Tuber Quality to Combined Application Cattle Manure and Inorganic Fertilizer. Specific gravity is one component of potato tuber quality which may or may not affect by integrated use of inorganic and organic fertilizer. According to Ababulgu (2018), it was a significant effect from the interaction of blended NPS fertilizer and cattle manure application. In this case, the maximum tuber specific gravity (1.089) was obtained from the control treatment. On other hand, tuber dry matter content was another component of potato quality that significantly affected by the interaction of blended NPS and cattle manure fertilizer (Ababulgu, 2018). According to Wondimu and Dechassa (2011), the interaction effect of P and FYM was significant on the specific gravity of the potato tubers produced. Thus, tubers with the highest specific gravity were produced at the combined application of $92 \mathrm{~kg} \mathrm{P} \mathrm{O} 5 \mathrm{ha}^{-1}$ and $20 \mathrm{t} \mathrm{FYM} \mathrm{ha}^{-1}$ as well as $46 \mathrm{~kg} \mathrm{P2O5}$ and $10 \mathrm{t} \mathrm{FYM} \mathrm{ha}{ }^{-1}$. This result indicated that the application of high amounts of P and FYM was instrumental in obtaining tubers with a high specific gravity which is indicative of high starch content and quality. The lowest specific gravity occurred at the lower rates of combined P and FYM application. Specific gravity is also an indication of tuber dry matter content.

The highest tuber dry matter content $(24.37 \%)$ was obtained from the control treatment (Bekele, 2018). Tuber starch content was significantly influenced by the interaction of blended NPSZnB fertilizer and cattle manure application (Bekele,2018). According to Bekele (2018), the combined application of blended NPSZnB fertilizer and cattle manure resulted in a significant reduction in tuber dry matter content and tuber starch content. Mohammed et al. (2018), the combination of different rates of inorganic fertilizer ( $\mathrm{N}$ and $\mathrm{P}$ ) with various levels of farmyard manure (FYM) caused significant differences in tuber dry matter yield.

\subsubsection{Potato Tuber Quality}

The quality is associated with nutritional value and suitability for a wide range of cooking purposes. Quality is one of the most important characteristics of potato and its quality is dependent on the external and internal aspects of the tuber (Abebe et al., 2013). Quality components of potato explained as specific gravity, dry matter content, texture, starch, etc.

\subsubsection{Dry matter content}

The dry matter content of tuber is an important measure of quality and is used to assess suitability for processing purposes as it affected process efficiency, product yield, and oil absorption. It was observed that tubers with high dry matter content required less energy input during frying or dehydration to remove water; resulted in greater product yield per unit fresh weight than tubers with lower solids content and absorbed less oil during frying 
(Abera,2001). According to Bekalo (2017), significantly lower tuber percent of dry matter was recorded in plot amended with recommended doses of NP than that all other treatments, whose dry matter contents.

The main effects of organic and inorganic fertilizer showed a significant difference for tuber dry matter yield. The treatment that received a recommended dose of $111 \mathrm{~kg} \mathrm{~N} \mathrm{ha}^{-1}$ and $92 \mathrm{~kg} \mathrm{P}_{2} \mathrm{O}_{5} \mathrm{ha}^{-1}$ fertilizer significantly increased tuber dry matter yield. Similarly, the effect of a 5-ton FYM ha ${ }^{-1}$ application on tuber dry matter yield was statistically significant compared to the control treatment (Mohammed et al., 2018). Figure 3 shows the response of potato dry matter to blended (NPS) and cattle manure. Increasing the rate of potassium $200 \mathrm{~kg} \mathrm{KCl}$ $\mathrm{ha}^{-1}$ did does not affect the total dry biomass yield of the potato. However, increasing the rate of potash from nil to $100 \mathrm{~kg} \mathrm{KCl} \mathrm{ha}^{-1}$ slightly increased dry matter yields by about $0.3 \%$. Thus, decreasing the rate of potash from 200 to $100 \mathrm{~kg} \mathrm{KCl} \mathrm{ha}^{-1}$ fertilizer rates increased the total dry matter content by about $8.13 \%$ (Amdie et al., 2018). Figure3.Response of potato dry matter to blended (NPS) and cattle manure (Ababulgu, 2018)
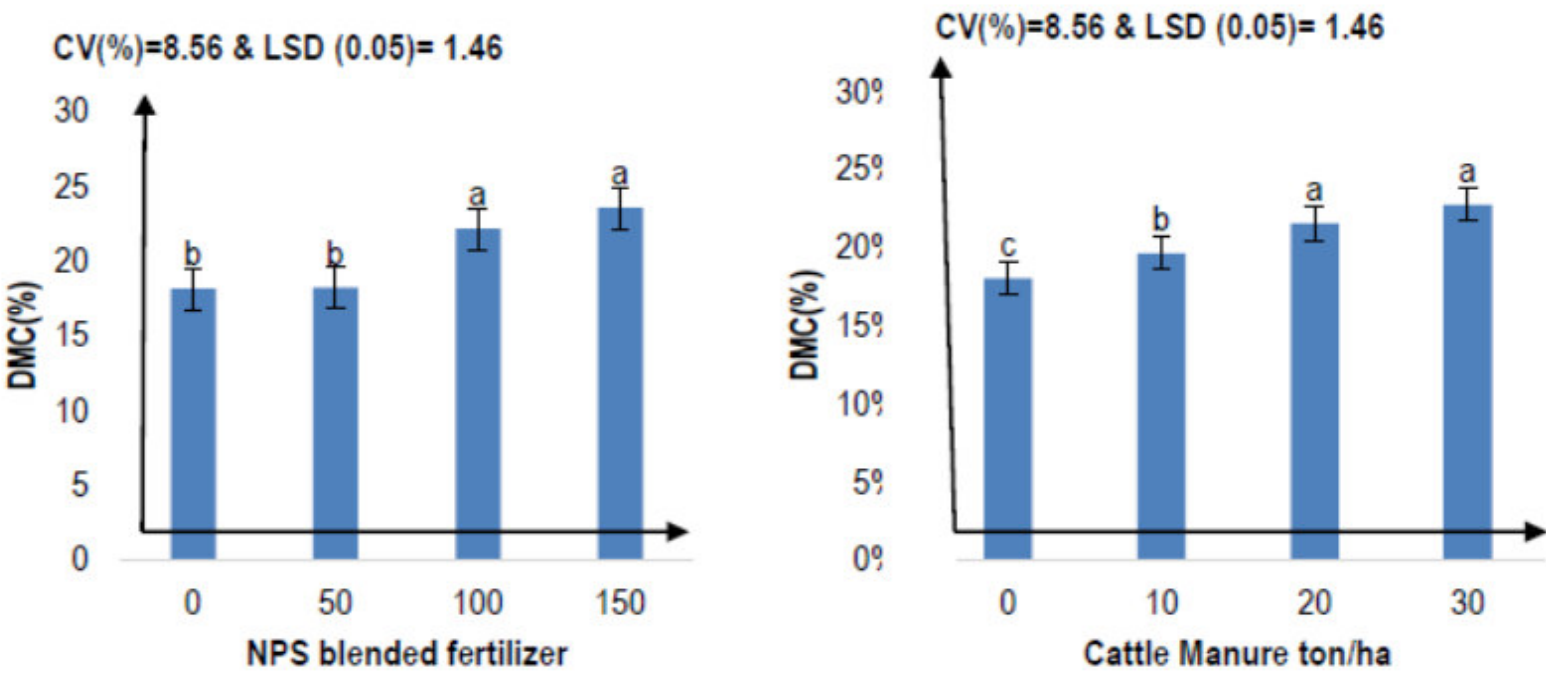

\subsubsection{Specific gravity}

The specific gravity of raw potatoes is widely accepted by the potato processing industry as a measure of total solids, starch content, and other qualities. High, uniform specific gravity in potato tubers is important to the grower and the processor. Nitrogen fertilization significantly reduced both tuber specific gravity and dry matter content which may be associated with the influence of $\mathrm{N}$ on gibberellins biosynthesis and other phytohormonal activities that have a direct influence on plant growth and dry matter accumulation (Zelalem et al., 2009).

According to Bekele (2018), the specific gravity of tubers was significantly affected by blended NPSZnB fertilizer and highly significantly affected by cattle manure. The maximum tuber specific gravity (1.089) was obtained from control treatment which is statistically not different from the application of $65.7 \mathrm{~kg}^{-1} \mathrm{blended}$ NPSZnB fertilizer $133 \mathrm{~kg} \mathrm{ha}^{-1}$ blended NPSZnB fertilizer, $10^{-1}$ cattle manure and $20 \mathrm{t} \mathrm{ha}^{-1}$ cattle manure. On other hand, the lowest value was recorded from the application of $199 \mathrm{~kg} \mathrm{ha}^{-1}$ blended NPSZnB fertilizer and $30 \mathrm{tha}$ ${ }^{1}$ cattle manure

\subsubsection{Starch}

Starch content has a direct influence on technological quality, especially concerning the texture of the processed products; it has significant importance for starch production in starch processing industries (Weldewahid et al., 2016). The application of $200 \mathrm{~kg} \mathrm{KCl} \mathrm{ha}^{-1}$ fertilizer rates did not produce significantly different starch yield 100 $\mathrm{kg} \mathrm{KCl} \mathrm{ha}^{-1}$ fertilizer rate. Increasing the rate of potassium $100 \mathrm{~kg} \mathrm{KCl} \mathrm{ha}^{-1}$ affects total starch yield of potato and produce the highest total starch content (17.23). While the lowest total starch content (15.63) was obtained the plots that received a $200 \mathrm{~kg} \mathrm{KCl}$ fertilizer rate. Thus, increasing the rate of potash from nil to $100 \mathrm{~kg} \mathrm{ha}^{-1} \mathrm{KCl}$ fertilizer rates slightly increases total starch content by about 10.24\% (Abebe, 2013).

Tuber's starch content and total starch yield were significantly influenced by variety and fertilizer but not by the interaction of the two. The highest starch content of 15.88 and $16.17 \%$ was obtained from tubers of belete variety and from plots that did not receive fertilizer respectively. On the other hand, the lowest starch content of 14.72 and $14.75 \%$ was observed in tubers of variety Bubu and for plots that received blended fertilizer, respectively. However, the total starch yield was higher for plots with $184 \mathrm{~kg} \mathrm{~N} \mathrm{ha}^{-1}\left(8.17 \mathrm{t} \mathrm{ha}^{-1}\right)$ and blended fertilizer $(8.11 \mathrm{t}$ $\left.\mathrm{ha}^{-1}\right)$ as well as for variety Gudanie $\left(7.74 \mathrm{t} \mathrm{ha}^{-1}\right)$, while the lowest values were recorded for plots that did not receive fertilizer and for variety Bubu. Plots with the highest tuber starch content did not produce the highest total starch yield (Weldewahid et al., 2016). Bekele (2018) described that tuber starch content was significantly influenced by blended NPSZnB fertilizer application; cattle manure application, and their interaction. The highest tuber starch content $(15.7 \mathrm{~g} / 100 \mathrm{~g})$ was obtained from the control treatment. The starch content recorded from the control 
treatment was $86.90 \%$ greater than that obtained from the combined application of $199 \mathrm{~kg} \mathrm{ha}^{-1}$ blended NPSZnB fertilizer and $30 \mathrm{t} \mathrm{ha}^{-1}$ cattle manure.

\section{SUMMARY AND CONCLUSION}

Inorganic and organic fertilizers are the main determinant factors limit yield and quality components of potato. Thus, this paper is designed to review the effect of various inorganic and cattle manure fertilizer on yield and tuber quality of potato. Tuber yield of potatoes; like, total tuber yield, marketable tuber yield, tuber diameter, and unmarketable tuber yield are highly influenced by the application of inorganic and cattle manure fertilizer. Quality components of potato tubers were tuber dry matter, specific gravity, and starch also limited by the application of inorganic and cattle manure fertilizer. In addition to that, the interaction effect of different inorganic and cattle manure fertilizer is also limited both yield and quality tuber of the potato. Application of nitrogen, phosphorous, potassium, and different blended fertilizer such as NPSB, NPS, KCL, and NPSZnB is the most widely known inorganic fertilizer influences yield and tuber quality of potato in Ethiopia. In terms of organic fertilizer cattle manure are the major animal wastes limit yield and quality of potato. Besides, the combined use of those inorganic and cattle manures are also highly determined the yield and quality of potato. Also, the combined application of inorganic and organic fertilizer suggested having more advantage in that it reduces cost, better for soil structure and increase yield and quality of potato. Besides that, cattle manure has the potential to improve the structure of the soil and enabled it to increase the water-holding capacity of the soil. On other hand, extensive use of inorganic fertilizer in crop production has a negative impact on the soil. Generally, the combined use of inorganic and organic fertilizer is advisable in yield and quality components of potato that's why it requires low fertilizer cost, improve soil structure, and enabled to increase yield and quality of the crop than the alone application of both fertilizers.

\section{REFERENCE}

Ababulgu AA. (2018). Integrated use of NPS blended fertilizer and cattle manure on growth, yield and quality of potato (Solanum tuberosum L.) under Dabo Ghibe Kebele, Seka Werada of Jimma Zone, Southwest Ethiopia. MSc thesis in Agronomy. Jimma, Ethiopia: Jimma University

Abebe T, Wongchaochant S, Taychasinpitak T. (2013). Evaluation of specific gravity of potato varieties in Ethiopia as a criterion for determining processing quality. Kasetsart J (Nat. Sci.), 47, pp.30-41.

Ahmed AA, Zaki MF, Shafeek MR, Helmy Y I, Abd El-Baky MM H .(2015). Integrated use of farmyard manure and inorganic nitrogen fertilizer on growth, yield, and quality of potato (Solanum tuberosum L.). International Journal Current. Microbiology. App. Sci,4(10), pp.325-349.

Amdie A, Dechassa N,Muhammed W. (2018). The response of Potato Solanum Tuberosum L. to Blended NPS and Potassium Fertilizers at Bore, Southern Ethiopia (Doctoral dissertation, Haramaya University).

Balemi T.( 2012). Effect of integrated use of cattle manure and inorganic fertilizers on tuber yield of potato in Ethiopia. Journal of Soil Science and Plant Nutrition, 12 (2): 253-261.

Bekalo GT. (2017). Potato Productivity, Nutrient Uptake and Use Efficiency as Influenced by Organic and Inorganic Amendments in Arbegona district, Southern Ethiopia (Msc thesis in soil science, Hawassa University).

Bekele B G, Belew D, Abebe T.(2018). NPSZnB Fertilizer and Cattle Manure Effect on Potato (Solanum tuberosum L.) Yield and Yield Components in Awi Zone, Ethiopia. International Journal of Soil Science, 13, pp.35-41.

Bekele G.(2018). Effect Of Blended NPSZnB fertilizer and Cattle Manure Rates On Growth, Yield And Quality Of Potato (Solanum Tuberosuml.) At Banja District, Awi Zone, North Western Ethiopia (Doctoral Dissertation, Jimma University).

Belachew B. (2016). Effects of Nitrogen, Potassium and prosperous rate and timing on yield and quality performances of potato under irrigated farming system (Doctoral dissertation, Jimma University).

Biruk M. (2015).Response of Potato (Solanum tuberosum L.) to Fertilizer Application and Post-Harvest Tuber Treatment with Plant Essential Oil Extracts in North- Eastern Ethiopia.Ph.D. Dissertation. School of Graduate Studies Haramaya University, Haramaya, Ethiopia.

CSA .(2013).Report on Area and production of major crops Thomas G Chastain Yield Components and Crop Yield.

CSA.( 2017).Agricultural Sample Survey Report on Area and Production (Private Peasant Holdings Meher Season. Central Statistical Agency of Ethiopia, Statistical Bulletin.

Gedam VB, Rametke JR, Rudragouda, Power,MS .(2008). Influence of organic manures on yield, nutrient uptake and change in physico-chemical properties of soil after harvest of groundnut. Crop Research, 36, $111^{-1} 14$.

Haverkort AJ, Koesveld MJ, van Schepers HTAM, Wijnands JHM, Wustman R, Zhang XY. (2012).Potato prospects for Ethiopia: on the road to value addition. Lelystad: PPO-AGV, 2012 (PPO publication 528), 66p.

Hirpa A, Meuwissen MPM, Tesfaye A, Lommen WJM, Lansink AO, Tsegaye A, Struik, PC. (2010). Analysis of seed potato systems in Ethiopia. American Journal of Potato Research, 87: 537-552. 
Khadem SA, Galavi M, Ramrodi M, Mousavi SR, Rousta MJ, Rezvani-Moghadam P. (2010). Effect of animal manure and superabsorbent polymer on corn leaf relative water content, cell membrane stability and leaf chlorophyll content under dry condition. Aus. J. Crop Sci. 4 (8): pp.642-647.

Koroto S. (2019). Effect of Farmyard Manure and Mineral NP Fertilizers on Yield Related Traits and Yield of Potato (Solanum tuberosum L.) at Areka, Southern Ethiopia. International Journal of Horticultural Science and Ornamental Plants 5(1): 074-085.Merga,

MoARD (Ministry of Agriculture and Rural Development). 2011. Animal and plant health regulatory directorate. Crop variety register issue No. 12. Addis Ababa, Ethiopia.

Mohammed A, Mohammed M, Dechasa N, Abduselam F. (2018) Effects of Integrated Nutrient Management on Potato(SolanumtuberosumL.) Growth, Yield and Yield Components at Haramaya Watershed, Eastern Ethiopia.

NajmAA, Haj Seyed Hadi M R, Fazeli F, Darzi MT, Rahi A. (2012a). Effect of integrated management of nitrogen fertilizer and cattle manure on the leaf chlorophyll, yield and tuber glycoalkaloids of Agria Potato.Commun. Soil Sci. Plant Anal., 43(6): 912923.

Negassa W, Negisho K, Friesen D K, Ransom J, Yadessa A. (2001).Determination of Optimum Farmyard Manure and NP Fertilizers for Maize on Farmers Field. Seventh Eastern and Southern Africa Regional Maize Conference. 11 th $^{-1} 5$ thFebruary. 387-393.

Paulos D, Asgelil D, Asfaw Z, Gezahegn A, Abebe, K. (2002). Advances in Vertisols management in the Ethiopian highlands. Proceedings of the International Symposium on Vertisol Management. Debre Zeit, Ethiopia

Siraj M, Mohammed W,Tana, T (2018). Effects of Blended NPSB Fertilizer Rates on Growth, Yield and Yield Related Traits of Potato Solanum tuberosum L. Varieties under Irrigation in Degem District, Central Highland of Ethiopia (Doctoral dissertation, Haramaya University).

Tesfaye G, Derbew B, Tulu S. (2012). Yield and Growth Parameters of Potato (Solanum tuberosum L.) as Influenced by Intra Row Spacing and Time of Earthing Up: In Boneya Degem District, Central Highlands of Ethiopia. International Journal of Agricultural Research, 7:255-265.

Tewodros A, Paul C. Adane H. (2014). Characterization of seed potato (Solanum tuberosum L.) Storage, preplanting treatment and marketing systems in Ethiopia: the case of west-arsizone. African journal of agricultural research, 9(15): pp.1218-1226.

Weldewahid G, Hadgu F, Gebresslasie G K. Mohammed W.(2016). Response of Potato Solanum tuberosum L. Varieties to Nitrogen and Blended Fertilizers Under Irrigation at Maichew, Southern Tigray, Ethiopia (Doctoral dissertation, Haramaya University).

Westermann DT. (2005).Nutritional requirements of potatoes.American Journal of Potato Research, 82: pp.301307.

Wondimu G, Dechassa N. (2011). Response of potato (Solanum tuberosum L.) to application of nitrogen, phosphorus, and farmyard manure at Debark, North-Western Ethiopia (Doctoral dissertation, Haramaya University).

Zelalem A, Tekalign T, Nigussie D. (2009). Response of potato (Solanum tuberosum L.) to different rates of nitrogen and phosphorus fertilization on vertisols at Debre Berhan, in the central highlands of Ethiopia. African Journal of Plant Science, 3(2), pp.016-024.

Zewide I, Mohammed A. Tulu S.( 2016). Effect of different rates of nitrogen and phosphorus on yield and yield components of potato (Solanum tuberosum L.) at Masha District, Southwestern Ethiopia. International Journal of Agricultural Research,11 (3): 95-104.

Zewide I, Tana T, Wogi L,Mohammed A.(2018). Effect of Combined Application of Cattle Manure, Mineral Nitrogen and Phosphorus Fertilizer on Soil Physico-Chemical Characteristics and Tuber Yield of Potato (Solanum tuberosum L.) in Masha District, South-western Ethiopia.

Zinash S. (2001). The role of livestock in crop-animal production system in Ethiopia. pp. 53- 58. 